\title{
CHARACTERISATION OF CORN EXTRUDATES WITH THE ADDITION OF BREWERS' SPENT GRAIN AS A RAW MATERIAL FOR THE PRODUCTION OF FUNCTIONAL BATTERS
}

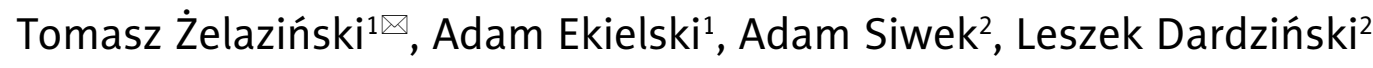 \\ 1Department of Production Management and Engineering, Warsaw University of Life Sciences - SGGW \\ Nowoursynowska 164, 02-787 Warsaw, Poland \\ ${ }^{2}$ Food Technology and Gastronomy Institute, Lomza State University of Applied Sciences \\ Akademicka 14, 18-400 Łomża, Poland
}

\begin{abstract}
Background. Novel food batters, recommended for various products, are at present manufactured by extrusion. Thanks to this, it is possible to look for and process new raw materials, if their processing has so far been considered impossible or economically unviable. The purpose of the work was therefore to investigate the extrudates produced from the corn and brewers' spent grain compounds that are subsequently used as raw material for food batter production.

Material and methods. The work presents the findings of research on extrusion of corn mixes with varying levels of brewers' spent grains, to the maximum amount of $30 \%$. Tests were conducted using a co-rotating double screw extruder, equipped with a single-outlet matrix with a diameter of $2.5 \mathrm{~mm}$. The products obtained were subjected to analysis of their parameters (apparent density, strength parameters, abrasiveness index) and the granulation of a single fraction was checked. The sample for which the percentage content was the highest was subjected to a detailed analysis of particle shape using vision software.

Results. It was found that an increase in the content of brewers' spent grains resulted in increased hardness of the products obtained. During the tests it was observed that the increasing hardness of the measured samples is opposite to their abrasion resistance. The maximum decrement of the brasion parameters was seen for extrudates with $30 \%$ spent grain addition and was $1.4 \%$, while the minimum decrement values for extrudates with brewers' grain content $(10 \%)$ amounted to $0.85 \%$. It was noted that this may prove the high brittleness of such products, particularly on the outer surface. It was also observed that lower grindability was recorded for samples produced by extrusion at a temperature of $140^{\circ} \mathrm{C}$. On the other hand, higher grindability obtained at a temperature of $120^{\circ} \mathrm{C}$ may facilitate the grinding of such products, which may be particularly important in the production of food batter.

Conclusion. Brewers' spent grains used as an addition to corn groats contribute to substantial changes in the extrudates obtained. It is also possible to produce compact extrudates with a brewers' spent grain content of $30 \%$. After grinding, extrudates with higher brewers' spent grain content are distinguished by more rounded grains. The packing index of the samples indicates the increased accuracy of covering products with such batter, which indicates an advantage of food batters containing brewers' spent grains.
\end{abstract}

Keywords: extrusion, brewers' spent grains, grinding, shape factor 


\section{INTRODUCTION}

The versatility of the extrusion process facilitates the search for and use of completely new materials, whose use has previously been either hindered or economically unviable. Such products include some glutenfree cereal materials, nut and sweet chestnut meals, as well as many other products, including exotic foods. Due to its specific characteristics, extrusion, through fast pressure and thermal processing, allows porous structures of many raw materials to be obtained, which has opened completely new possibilities of using these on a larger scale (Ekielski and Żelaziński, 2016; Moraru and Kokini, 2003). This has been confirmed by many research projects and articles in recent years, for instance, for the broad range of breakfast cereals, pastas, thickeners, meat analogs, natural colorants etc. (Makowska et al., 2015; Wójtowicz et al., 2015). This proves that the extrusion process still has substantial potential, and the search for new raw materials which can be adapted to direct consumption or constitute an addition to other foods is justified.

One of the raw materials which has so far mainly been treated as waste is brewers' spent grain. This fiber-rich material (Brennan et al., 2008; Eshak et al., 2010; O'Neil et al., 2010; Zhang and Zhang, 2011) is a waste product in the manufacturing of wort in breweries. As a standard, the production of 100 liters of beer generates 20 kilograms of by-products, of which brewers' spent grain constitutes 31\% (Reinold, 1997; Townsley, 1979). Thus far, most brewers' spent grain has been designated directly as fodder for ruminants. A barrier which hinders its broader use is its high water content, about $80 \%$, which in fact prevents storage of large quantities of this raw material. A few scientific articles have suggested that extruded raw cereals with brewers' spent grain content are characterized by a lower expansion ratio and increased density in comparison with standard products, e.g. those made of corn groats (Ainsworth et al., 2007; Makowska et. al., 2013; Nascimento et. al., 2017; Stojceska et al., 2008). It was also found that the addition of brewers' spent grain to extrudates may lead to the increased porosity of these products (Stojceska et al., 2008). Other authors have found that increasing the addition of brewers' spent grain in the extruded blend usually results in increased hardness and crispness in such products. (Ainsworth et al., 2007). Ktenioudaki et al. (2013) state that an increase in the hardness of extrudates, along with an increase in the share of brewers' spent grain, may be one of the factors that limits the popularity of such food products. An examination of extrudates containing brewers' spent grain (moisture $78 \%$ ) brewers' spent grain used directly for extrusion) was conducted by Siwek et al. (2014), who found the possibility of using this raw material as an additive to extruded products. However, most research projects conducted found a relatively low content of this raw material in the mixture (which usually ranges from a few to slightly more than ten percent of the dry ingredient, a maximum of $30 \%$ with rice) (Nascimento et al., 2017). Taking into account the above, it is necessary to examine more thoroughly the impact of brewers' spent grain (particularly in larger doses) on the properties of cereal extrudates.

Summing up, it can be stated that the results obtained so far refer to a small group of products. It is therefore justified to search for new applications for extruded products with the share of brewers' spent grains, such as food batter, meat dishes, fish and others.

The objective of the work was to examine the impact of adding dry brewers' spent grains on the selected qualities of corn extrudates to be used as food batter.

\section{MATERIAL AND METHODS}

The research material used in the research project was a mixture of cereal raw materials, that is, corn groats (granule size 0.16-0.60 mm) purchased from Silesian Grain Sp. z o.o. and brewers' spent barley grains obtained from the production of wort on a laboratory scale at the Institute of Food Technology and Nutrition of the Lomza State University of Applied Sciences (dried to a moisture level of 10\%). From the above raw material, 3 mixtures were formed, containing 10 , 20 and $30 \%$ brewers' spent grains.

The research was conducted using a double-screw co-rotating laboratory extruder Evolum 25 (producer: CLEXTRAL, Firminy, France) with a screw length to diameter ratio of $27: 1$. In the extruder head, a matrix with a single round outlet nozzle with a diameter of $2.5 \mathrm{~mm}$ was installed. The process temperature in the plasticizing section was $120^{\circ} \mathrm{C}$ and $140^{\circ} \mathrm{C}$ (temperature profile setpoints in the extruder cylinder, from the 
Żelaziński, T., Ekielski, A., Siwek, A., Dardziński, L. (2017). Characterisation of corn extrudates with the addition of brewers' spent grain as a raw material for the production of functional batters. Acta Sci. Pol. Technol. Aliment., 16(3), 247-254. http://dx.doi. org/10.17306/J.AFS.2017.0487

Table 1. Characteristics of raw materials used in the experiment

\begin{tabular}{lcc}
\hline \multicolumn{1}{c}{ Raw material } & Corn groats, \% d.m. & Brewers' spent grains, \% d.m. \\
\hline Moisture & $13.3 \pm 0.66$ & $10 \pm 0.1$ \\
Total fat & $0.7 \pm 0.04$ & $8.1 \pm 0.41$ \\
Proteins & $8.4 \pm 0.42$ & $27.5 \pm 0.28$ \\
Starch & $74 \pm 0.74$ & $3.4 \pm 0.17$ \\
Cellulose & $1.48 \pm 0.08$ & $17.2 \pm 0.17$ \\
Mineral substances & - & $7.5 \pm 0.08$ \\
Non-anoxic substances of the extract & - & $39 \pm 0.40$ \\
\hline
\end{tabular}

feeding section (inlet) to the plasticizing section (material outlet): $60,80,110,110,120^{\circ} \mathrm{C}$ and $60,80,110$, $\left.110,140^{\circ} \mathrm{C}\right)$. The extruder screw speed was set to 300 $\mathrm{rpm}$. The raw material feed rate was $5.5 \mathrm{~kg} \cdot \mathrm{h}^{-1}$. During the process, the material was moistened with water using a mechanical dispenser with an accuracy of $0.001 \mathrm{~cm}^{3}$, and was equipped with the extrusion line set. This allowed a mixture with a moisture level of $14 \%$ to be obtained. Before starting the extrusion process, the raw material moisture was performed in a Radwag WPS 210 moisture analyser. The extruder head had a cutter with a triple rotating knife, making it possible to obtain $8 \pm 0.5 \mathrm{~mm}$ length extrudates. After cooling, the extrudate samples were stored in plastic bags.

The extrudate samples were analyzed. The following quality parameters were checked:

- Extrudate apparent density, according to the ASAE Standard (ASAE S269.3:1989).

- Strength parameters. The tests were performed using an AXIS FM 500 strength test device (producer: AXIS, Gdansk, Poland) equipped with heads of a maximum force of $250 \mathrm{~N}$ with a rounded mandrel (diameter of $1.5 \mathrm{~mm}$ ) for puncturing the top layer of the extrudate sample (Ding et al., 2006). Each sample was placed horizontally in the machine handle. The head speed was $0.4 \mathrm{~mm} \cdot \mathrm{s}^{-1}$. The results were recorded using AXIS FM software. The measurement result for a single sample was the maximum value of strength needed to puncture the extrudate sample.

- Grindability. The test was performed using a special device for grindability tests (Automated tablet friabilator EF2W (producer: Electrolab, Mumbai,
India). A single test lasted 4 minutes. The grindability test was performed on the basis of standard PN-EN ISO 17831-1:2016-02 Solid biofuels - pellets. In the next stage of research, extrudate samples were ground using a Bosch MKM 6000 impact mill (grinding time $5 \mathrm{~s}$ ), and the product obtained was subjected to sieve analysis using a sieve classifier LPzE-2e (producer: Multserw, Brzeźnica, Poland). 7 sieves were used with a mesh size of \# 0.15, 0.25, 0.5, 0.8, 1; 1.6, $2 \mathrm{~mm}$ (DIN ISO 3310-1). The vibration amplitude used was $A=6$ $\mathrm{mm}$, the vibration frequency $f=2,00 \mathrm{~Hz}$, over time $t=10$ minutes.

The crushed samples were separated on the basis of the size fraction, and the fraction with the largest percentage share (obtained on the sieve) was subjected to image analysis (IMAQ..., 2006). This investigation of shape factors (Heywood shape factor and Compactness Factor) was performed using Ni Vision Assistance 2015 software produced by National instruments. The samples of particulate extrudate were spread on black paper and then photographed in a lightbox equipped with D65 fluorescent lamps using a color camera ac A2500 - 14uc (5 Mpx) (producer: Basler, Ahrensburg, Germany).

The research findings were analysed using StatSoft, Inc. (2012) STATISTICA version 10. The results were presented in box plots in which individual variables were connected by auxiliary lines. The significance of data was analyzed using the ANOVA test. The course of variables on the chart was additionally analyzed using the correlation coefficient. The tests were done in 5 replications. 


\section{RESULTS}

All of the corn-brewers' spent grains extrudates obtained were characterized by a uniform structure (porous in the cross-section), which is typical for products manufactured in this manner, and had a high level of starch raw materials. In many works on the cooking extrusion of food raw materials, the authors point to the typical porous structure of extrudates, in which the product structure is based on a rigid matrix of gelatinized starch and fused protein fibers (Moscicki, 2011).

It was found that as the brewers' spent grain content increased, so did the apparent density of extrudates, which for samples containing 30\% brewers' spent grains (a process temperature of $120^{\circ} \mathrm{C}$ ) amounted to $0.114 \mathrm{~g} \cdot \mathrm{cm}^{-3}$. The density of samples obtained at $140^{\circ} \mathrm{C}$ was lower, amounting to $0.089 \mathrm{~g} \cdot \mathrm{cm}^{-3}$ for the same brewers' spent grain content (Fig. 1a). In the any case (for different brewers' spent grain ratio) were

Table 2. Correlation coefficients for brewers' spent grain $(10,20$ and 30\%) share in the mixture according to various quality parameters

\begin{tabular}{lcc}
\hline \multicolumn{1}{c}{ Variable } & $\begin{array}{c}\text { Discharge extrusion } \\
\text { (directly before die) } \\
120^{\circ} \mathrm{C}\end{array}$ & $\begin{array}{c}\text { Discharge extrusion } \\
\text { (directly before die) } \\
140^{\circ} \mathrm{C}\end{array}$ \\
\hline Density, $\mathrm{g} \cdot \mathrm{cm}^{-3}$ & $0.968^{\mathrm{a}}$ & $0.983^{\mathrm{a}}$ \\
Grindability, \% & $0.928^{\mathrm{a}}$ & $0.860^{\mathrm{a}}$ \\
Force, $\mathrm{N}$ & $0.978^{\mathrm{a}}$ & $0.939^{\mathrm{a}}$ \\
Compactness factor & $0.711^{\mathrm{a}}$ & $0.833^{\mathrm{a}}$ \\
Heywood circularity factor & $-0.986^{\mathrm{a}}$ & $0.871^{\mathrm{a}}$ \\
\hline
\end{tabular}

Correlation coefficients are significant for $p<0.05$.

aFor any brewers' spent grain share in the compound measure.

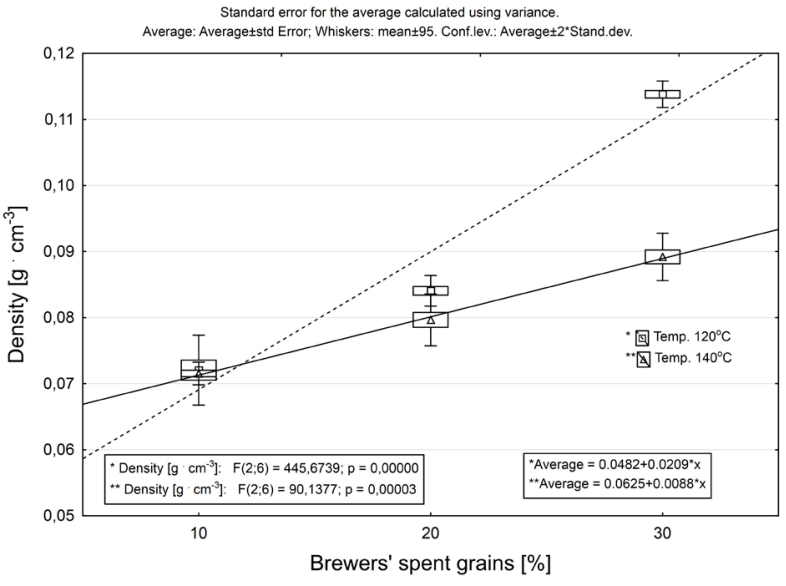

a

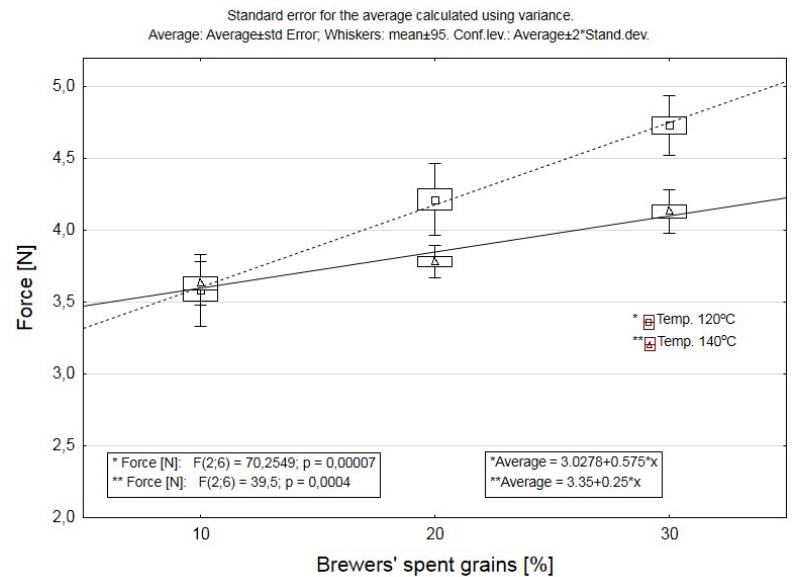

b

Fig. 1. Impact on the content of brewers' spent grains in the corn extrudates on: $a$ - extrudate density, $b$ - maximum force needed to puncture the extrudate sample. Test F results and values (ANOVA) are presented for each process temperature 
found very high correlation was recorded at the level of 0.968 (temp. $120^{\circ} \mathrm{C}$ ) and 0.983 (temp. $140^{\circ} \mathrm{C}$; Table 2). Many other authors have also observed the decrease in product density as a result of the use of various additives being added to the mixture, predominantly proteins, fiber, cellulose (Jin et al., 1995; Makowska et al., 2013; Nascimento et al., 2017). Therefore, in order to reduce product density in production conditions, the process temperature is often increased, which, while improving the sensory characteristics of the product, at the same time visibly increases degradation of the food ingredients.

It was also found that extrudate hardness (maximum force needed to puncture the sample) increased gradually along with the content of brewers' spent grains, reaching a peak at the maximum brewers' spent grain content of $30 \%$ (Fig. 1b). A similar chart was observed for results obtained at a process temperature of $140^{\circ} \mathrm{C}$, however, in this case, a statistically significant hardness reduction in product resistance was found, particularly for brewers' spent grain content of 20 and $30 \%$. In both cases, the correlation coefficient values were also statistically significant, amounting to $(0.978)$ for $120^{\circ} \mathrm{C}$ and $(0.939)$ for $140^{\circ} \mathrm{C}$. The decreased resistance of these products, along with an increase in the process temperature may, in this case, be justified by a higher degree of gelatinization of starch, and the probable commencement of degradation of starch polymers under these temperature conditions. Similar trends have been noted by such authors as (Robin et al., 2011; Zhang et al., 2016). Increased resistance of extrudates containing brewers' spent grains could also be related directly to density, which, as has been noted above, increased along with the content of brewers' spent grain in the mixture.

The results of apparent density and resistance parameters of extrudates indicate that the increase in the share of brewers' spent grains contributes to obtaining harder and more compact products at the further stage of research. Subsequent resistance tests were undertaken to simulate the "grindability" of such products. The results obtained turned out to be surprising. Although the earlier data suggested higher resistance of extrudates containing brewers' spent grains, samples with $30 \%$ content of this raw material were ground more than others (Fig. 2). Their maximum mass (30\% brewers' spent grains added) decrement after staying

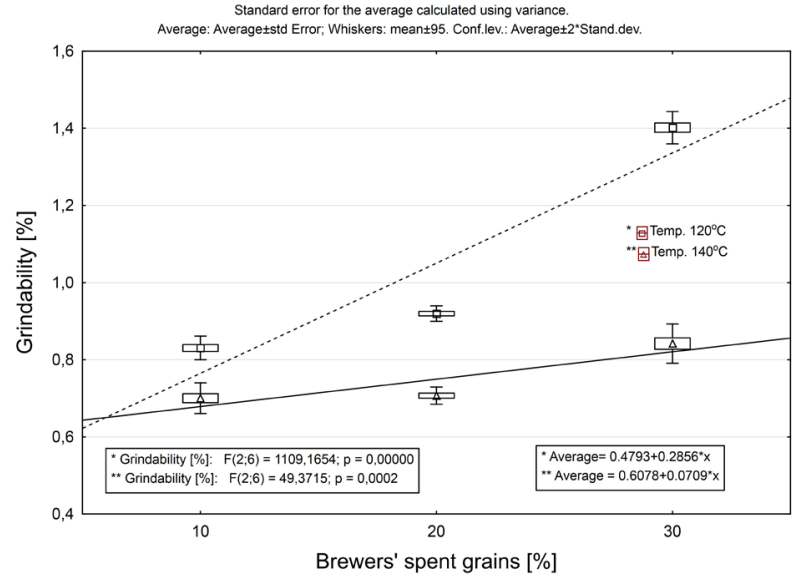

Fig. 2. Impact of the content of brewers' spent grains on extrudate grindability. Test $\mathrm{F}$ results and values (ANOVA) are presented for each process temperature

in the chamber of the device for 4 minutes was $1.4 \%$, while the minimum mass decrement in extrudates containing $10 \%$ brewers' spent grains amounted to $0.85 \%$. Therefore, it can be stated that extrudates containing $30 \%$ brewers' spent grains were almost two times less resistant to "grinding" in comparison with extrudates with the lowest brewers' spent grain content. In this case, the diagrams reflected a tendency to increase, and high correlation coefficients at the level of 0.928 and 0.860 indicated significant changes in the diagrams. This may be a feature of the increased fragility of such products (mainly their outer surface). Research into the outer surface of extruded products has also been conducted (Alam et al., 2016). In their works, they point to the structure of the skin of extruded products, made up of glued and flattened pores, which are closed after steam has been discharged to the external environment. Applying large quantities of density-reducing additives may thus result in decreased resistance of this structure. It is also interesting that grindability was lower for samples produced at an extrusion process temperature of $140^{\circ} \mathrm{C}$. Therefore, for extrudates containing brewers' spent grains earmarked, for instance, for breakfast cereals, this may be the most appropriate temperature range in the extruder plasticizing section. On the other hand, higher grindability achieved at a temperature lower than $120^{\circ} \mathrm{C}$ may facilitate the grinding of such products 


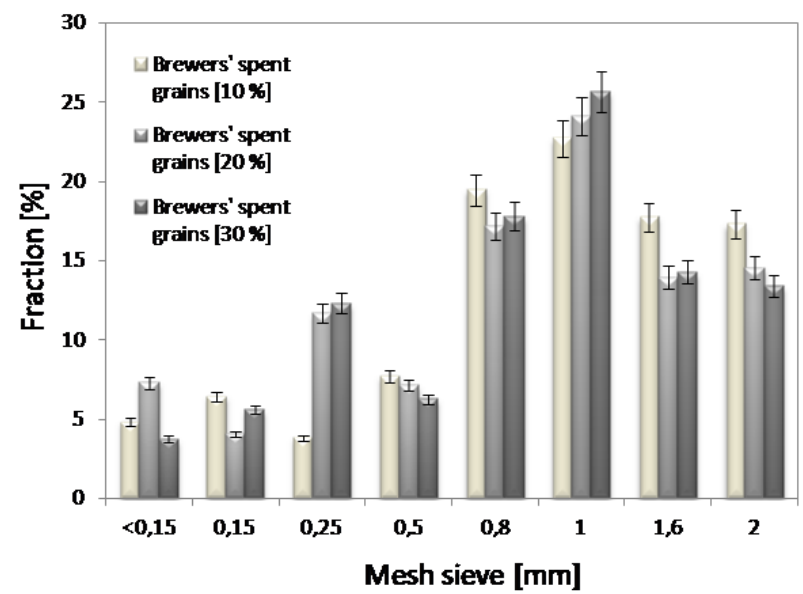

Fig. 3. Degree of granulation of ground extrudate (brewers' spent grain content 10,20 and $30 \%$, process temperature $\left.120^{\circ} \mathrm{C}\right)$

(e.g. decrease energy consumption of the grinding process), which may be particularly important in the production of food batter.

During the subsequent stage of research, the results of a sieve analysis of ground extrudate containing brewers' spent grains were presented for products manufactured at a process temperature of $120^{\circ} \mathrm{C}$ and $140^{\circ} \mathrm{C}$ (Fig. 3). Research was conducted to identify the highest percentage share of extrudate fraction. After sieve analysis, it was found that the share of fractions obtained for each sieve differed, and the largest was the fraction obtained with a sieve with a mesh size of $>1 \mathrm{~mm}$ (the fraction constituted $25.7 \%$ of total mass). For extrudates produced at $140^{\circ} \mathrm{C}$, the ratio of this fraction was $24.3 \%$.

A detailed analysis of this fraction in Figure $4 a, 4 b$ has also shown that as the content of brewers' spent grains increased in the ground products, the following factors also changed: Heywood Circularity Factor (HCF) and the batter particle packing factor - compactness factor (CF). In this case, the changes in all diagrams were statistical significant and confirmed by the correlation coefficients presented in Table 2. It was found that HCF factors exhibited a statistically significant decrease along with the content of brewers' spent grain in the product, and thus the particles were more rounded in this case. On the other hand, the CF coefficient values increased, which indicates the better potential of surface coverage with such batter. This may be of key significance in the use of such batter on meat and fish products, which has also been indicated by such authors as Martínez et al. (2015).

It was also found that the changes in the shape coefficients of samples obtained at $120^{\circ} \mathrm{C}$ were more

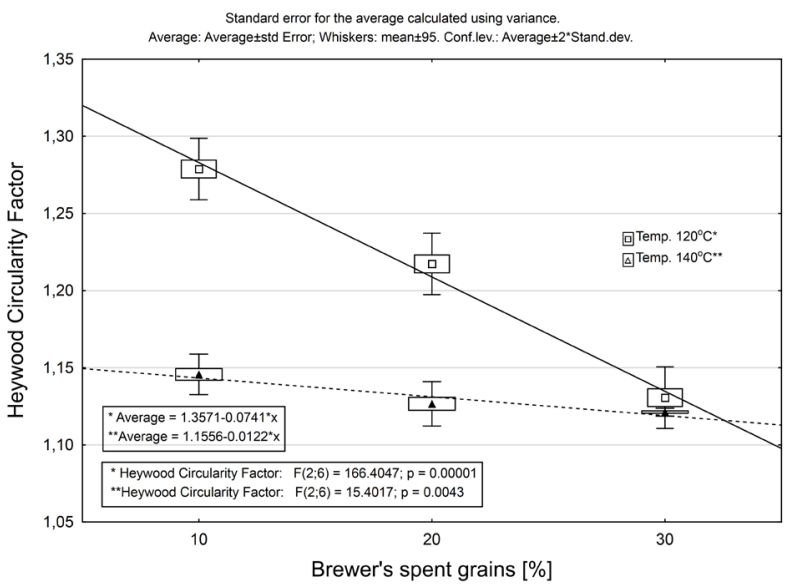

a

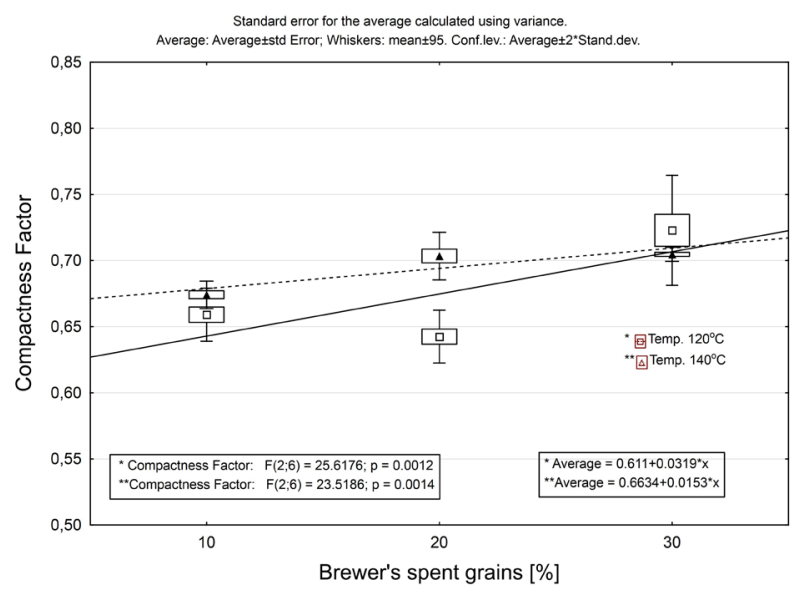

b

Fig. 4. Impact of the content of brewers' spent grain on: a - heywood circularity factor, $b$ - compactness factor of the ground extrudate fraction (fraction obtained on $1 \mathrm{~mm}$ mesh sieve). Test $\mathrm{F}$ results and values (ANOVA) are presented for each process temperature 
intense compared to those obtained at $140^{\circ} \mathrm{C}$. In all cases, the variation between the points was significant, which was confirmed by the correlation coefficients shown in Table 2.

\section{CONCLUSION}

1. Brewers' spent grains used as an additive to corn groats results in significant changes in the properties of the extrudates obtained.

2. It is possible to produce extrudates containing $30 \%$ brewers' grains; however, they will be characterized by higher hardness in comparison with extrudates with a lower level of brewers' spent grain in the processed compounds.

3. Lowering of extrusion process temperature for mixtures containing maize and spent grain from $140^{\circ} \mathrm{C}$ to $120^{\circ} \mathrm{C}$ allows products with reduced grinding resistance to be manufactured.

4. An increase in the content of brewers' grains in ground products results in more rounded extrudate fractions. At the same time, compacting factor $\mathrm{CF}$ indicates greater accuracy of coverage of products with such batter, which has a positive impact on the product quality when designated for manufacturing food batter.

\section{REFERENCES}

Ainsworth, P., İbanoğlu, Ş., Plunkett, A., İbanoğlu, E., Stojceska, V. (2007). Effect of brewers spent grain addition and screw speed on the selected physical and nutritional properties of an extruded snack. J. Food Eng., 81(4), 702 709. http://dx.doi.org/10.1016/j.jfoodeng.2007.01.004

Alam, S. A., Pentikäinen, S., Närväinen, J., Holopainen-Mantila, U., Poutanen, K., Sozer, N. (2016). Effects of structural and mechanical textural properties of brittle cereal foams on mechanisms of oral breakdown. Food Res. Int. http://dx.doi.org/10.1016/j.foodres.2016.11.026

ASAE Standard (1989). ASAE S269.3. Wafers, pallets, and crumbles - definitions and methods for determining density, durability and moisture content.

Brennan, M., Monro, J. A., Brennan, C. S. (2008). Effect of inclusion of soluble and insoluble fibres into extruded breakfast cereal products made with reverse screw configuration. Int. J. Food Sci. Technol., 43, 2278-2288. http://dx.doi.org10.1111/j.1365-2621.2008.01867.x
Ding, Q. B., Ainsworth, P., Plunkett, A., Tucker, G., Marson, H. (2006). The effect of extrusion conditions on the functional and physical properties of wheat-based expanded snacks. J. Food Eng., 73(2), 142-148.

DIN ISO 3310-1 (2001-09). Test sieves - Technical requirements and testing. Part 1: Test sieves of metal wire cloth.

Ekielski, A., Żelaziński, T. (2016). Application of Weibull distribution for predicting the distribution of cereal extrudate fractions. Ann. Warsaw Univ. Life Sci. - SGGW, Agriculture (Agric. For. Eng.), 67, 139-147.

Eshak, E. S., Iso, H., Date, C., Kikuchi, S., Watanabe, Y., Wada, Y. (2010). Dietary fiber intake is associated with reduced risk of Mortality from cardiovascular disease among Japanese men and women. J. Nutr., 140, 14451453. https://doi.org/10.3945/jn.110.122358

IMAQ Vision Concepts Manual (2005). Austin, USA: National Instrument.

Jin, Z., Hsieh, F., Huff, H. E. (1995). Effects of soy fiber, salt, sugar and screw speed on physical properties and microstructure of corn meal extrudate. J. Cereal Sci., 22(2), 185194. https://doi.org/10.1016/0733-5210(95)90049-7

Ktenioudaki, A., Crofton, E., Scannell, A. G. M., Hannon, J. A., Kilcawaley, K. N., Gallagher, E. (2013). Sensory properties and aromatic composition of baked snacks containing brewer's spent grain. J. Cereal Sci., 57, 384390. http://dx.doi.org/10.1016/j.jcs.2013.01.009

Makowska, A., Mildner-Szkudlarz, S., Obuchowski, W. (2013). Effect of brewer's spent grain addition on properties of corn extrudates with an increased dietary fibre content. Polish J. Food Nutr. Sci., 63(1), 19-23. https:// doi.org/10.2478/v10222-012-0061-9

Makowska, A., Polcyn, A., Chudy, S., Michniewicz, J. (2015). Application of oat, wheat and rye bran to modify nutritional properties, physical and sensory characteristics of extruded corn snacks. Acta Sci. Pol. Technol. Alim., 14(4), 375-386. http://dx.doi.org/10.17306/J. AFS.2015.4.37

Martínez, M. M., Sanz, T., Gómez, M. (2015). Influence of wheat flour subjected to different extrusion conditions on the rheological behaviour and thermal properties of batter systems for coating. LWT - Food Sci. Technol., 64(2), 1309-1314. http://dx.doi.org/10.1016/j. lwt.2015.07.037

Moraru, C. I., Kokini, J. L. (2003). Nucleation and expansion during extrusion and microwave heating of cereal foods. Compr. Rev. Food Sci. Food Safety, 2, 147-165. http://dx.doi.org/10.1111/j.1541-4337.2003.tb00020.x

Moscicki, L. (Ed.). (2011). Extrusion-cooking techniques: applications, theory and sustainability. John Wiley \& Sons. 
Nascimento, T. A., Calado, V., Carvalho, C. W. (2017). Effect of Brewer's spent grain and temperature on physical properties of expanded extrudates from rice. LWT - Food Sci. Technol., 79, 145-151. http://dx.doi. org/10.1016/j.lwt.2017.01.035

O’Neil, C. E., Zanovec, M., Cho S. S., Nicklas T. A. (2010). Whole grain and fiber consumption are associated with lower body weight measures in US adults: National Health and Nutrition Examination Survey 1999-2004. Nutr. Res., 30, 815-822. http://dx.doi.org/10.1016/j. nutres.2010.10.013

PN-EN ISO 17831-1:2016-02. Biopaliwa stałe - Oznaczanie wytrzymałości mechanicznej peletów i brykietów. Część 1. Pelety.

Reinold, M. R. (1997). Manual pra'tico de cervejaria. Sao Paulo: Aden Editora e Comunicacoes.

Robin, F., Dubois, C., Schuchmann, H. P., Palzer, S. (2011). Supplementation of extruded foams with wheat bran: Effect on textural properties. Procedia Food Sci., 1, 505-512. https://doi.org/10.1016/j.profoo.2011.09.077

Siwek, A., Ekielski, A., Żelaziński, T., Nowak, D., Miarka, D., Żukowska, J., Bakuła, S. (2014). Wybrane właściwości ekstrudatów kukurydzianych z dodatkiem młóta browarnianego. Zesz. Probl. Post. Nauk Roln., 579, 79-89.
Stojceska, V., Ainsworth, P., Plunkett, A., İbanog `ulu, S. (2008). The recycling of brewer's processing by-product into ready-to-eat snacks using extrusion technology. J. Cereal Sci., 47(3), 469-479. https://doi.org/10.1016/j. jcs.2007.05.016

Townsley, P. M. (1979). Preparation of commercial products from brewer's waste grain and trub. MBAA Techn. Quart., 16, 130-134.

Wójtowicz, A., Mitrus, M., Oniszczuk, T., Mościcki, L., Kręcisz, M., Oniszczuk, A. (2015). Selected physical properties, texture and sensory characteristics of extruded breakfast cereals based on wholegrain wheat flour. Agric. Agric. Sci. Proced., 7, 301-308. https://doi. org/10.1016/j.aaspro.2015.12.051

Zhang, M., Zhang, Z. (2011). Extrusion process improves the functionality of soluble dietary fiber in oat bran. J. Food Sci., 54, 98-103. http://dx.doi.org/10.1016/j. jcs.2011.04.001

Zhang, W., Li, S., Zhang, B., Drago, S. R., Zhang, J. (2016). Relationships between the gelatinization of starches and the textural properties of extruded texturized soybean protein-starch systems. J. Food Eng., 174, 29-36. http:// dx.doi.org/10.1016/j.jfoodeng.2015.11.011 